Bangladesh J. Plant Taxon. 21(2): 175-180, 2014 (December)

(C) 2014 Bangladesh Association of Plant Taxonomists

\title{
SYSTEMATICS OF SISYRINCHIUM ANGUSTIFOLIUM MILL. (IRIDACEAE), A NEWLY RECORDED SPECIES FROM TURKEY
}

\author{
ÖZGÜR EMINAGAOGLU ${ }^{1}$ AND MELAHAT ÖZCAN² \\ Department of Forest Engineering, Faculty of Forestry, Artvin Coruh University, \\ 08000 Artvin-Turkey
}

Keywords: New record; Sisyrinchium; Anatomy; Chromosome number; Turkey.

\begin{abstract}
Sisyrinchium angustifolium Mill. (Iridoideae, Sisyrinchieae) has been reported as a new record for the flora of Turkey from NE Anatolia, and taxonomic and conservation status of this species are evaluated. Detailed morphological description, leaf and stem anatomical properties, and chromosome numbers are provided. The present chromosome count is the first tetraploid level for this species reported from Eastern Anatolia, Turkey.
\end{abstract}

\section{Introduction}

Sisyrinchium L. (Iridoideae, Sisyrinchieae) includes approximately 200 species (Rudall et al., 1986) and occurs in wet to dry grasslands, rocky or sandy soils, and also in highly transformed areas, such as roadsides or grazed and burned fields at elevations of up to $800 \mathrm{~m}$ (Bicknell, 1899). During fieldwork in Artvin Province (Turkey) some interesting specimens belonging to Iridaceae were collected. After critical study and consultation with relevant literature (Fedchenko, 1968; Davis, 1984, 1988; Güner et al., 2000; Özhatay et al., 2011), the specimens have been identified as Sisyrinchium angustifolium Mill. The species was not reported earlier from Turkey (Özhatay et al., 2011; Eminağaoğlu et al., 2012; Eminağaoğlu and Özcan, 2013) and hence reported as a new record for the flora of Turkey. S. angustifolium is the first species of the genus Sisyrinchium to have been reported for Turkey. The number of genera of Iridaceae in the flora of Turkey is increased to 6 with addition of Sisyrinchium. In this study, we aim to describe detailed morphological characters of Sisyrinchium angustifolium, to determine its conservation status, and distribution along with exploring the anatomical and cytological properties of the newly recorded species.

\section{Materials and Methods}

Morphological analysis: Plant materials were collected from distinct parts of Artvin, Turkey, at different altitudes in May and June, 2013. The collected materials were critically studied. The voucher specimens have been deposited at the Herbarium of Artvin Coruh University (ARTH), Artvin, Turkey.

Anatomical preparation: Anatomical observations were performed in stem and leaf from living specimens. Plant samples were stored in $70 \%$ alcohol for anatomical studies. Transverse sections of stem and leaf, and peripheral sections of upper and lower epidermis of leaves were taken by hand using commercial razor blades and stained in Haematoxylin for about 15 min. To remove the excess stain, sections were washed in water several times (Algan, 1981). Semipermanent slides were mounted in glycerin or permanent slides were covered with glycerin-gelatin

${ }^{1}$ Corresponding author. Email: oeminagaoglu@artvin.edu.tr

${ }^{2}$ Department of Biology, Faculty of Science and Arts, Artvin Coruh University, 08000 Artvin-Turkey 
(Vardar, 1987). Well stained sections were examined under a light microscope and photographed using an Olympus BX-53 microscope with digital camera attachment DP 73.

Chromosome count: For mitotic chromosome observation root tips growing in pots were cut off and pretreated with $0.05 \%$ colchicine at room temperature for 4.0-4.5 h (Ozcan et al., 2008), then fixed in fresh Carnoy absolute alcohol-glacial acetic acid $(3: 1)$ for $24 \mathrm{~h}$ at $4^{\circ} \mathrm{C}$. For chromosome counts, root tips were hydrolyzed in $5 \mathrm{~N} \mathrm{HCl}$ for 10-12 min at room temperature and then rinsed with distilled water for 2-3 min. Staining was carried out in lacto-propionic orcein at least for $2 \mathrm{~h}$ at room temperature. Permanent slides were prepared from at least ten well-spread cells. The best metaphase plates were photographed with Olympus BX-53 microscope with digital camera attachment DP 73.

\section{Results and Discussion}

Sisyrinchium angustifolium Mill. Gard. Dict., ed. 8. n. 2 (1768). Sisyrinchium angustifolium f. album J.K. Sim \& Y.S. Kim, Korean J. Pl. Taxon. 22: 3 (1992); Sisyrinchium hibernicum Á. Löve \& D. Löve, Bot. Not. 114: 37 (1961); Sisyrinchium membranaceum E.P. Bicknell, Bull. Torrey Bot. Club 26: 612 (1899); Bermudiana homomalla (Klatt) Kuntze, Revis. Gen. Pl. 2: 700 (1891); Sisyrinchium homomallum Klatt, Abh. Naturf. Ges. Halle 15: 378 (1882); Bermudiana graminea Gaertn., Fruct. Sem. Pl. 1: 32 (1788); Sisyrinchium gramineum Lam., Encycl. 1: 408 (1785).

(Fig. 1).

Caespitose, perennial herb, up to $40 \mathrm{~cm}$ tall. Stem erect or ascending, branched, conspicuously winged towards base, the wing 3-5 mm broad; with 1-2 nodes, 2.3-5.0 $\mathrm{mm}$ wide, glabrous, margin often minutely denticulate especially basally. Leaves radical, linear-ensiform, $3-5 \mathrm{~mm}$ broad, leaf blades glabrous. Flowers 1-4 in inflorescence, c. $15 \mathrm{~mm}$ in diameter; spathes usually green, wider than supporting branch, glabrous, keels denticulate to entire; outer 18-38 mm long, $2.0-9.5 \mathrm{~mm}$ longer than inner, usually tapering evenly towards apex, margin basally connate $4-6 \mathrm{~mm}$; inner with keel evenly curved or straight, hyaline, margin 0.1-0.3 mm wide, apex acuminate to acute, ending $0.2-0.7 \mathrm{~mm}$ proximal to green apex. Flowers pale blue to violet, occasionally white, bases yellow; outer tepals 7.7-12.5 mm long, apex rounded or emarginate, aristate. Stamens inserted at the base of perianth, the filaments usually more or less adnate to the tube, filaments connate \pm entirely, stipitate-glandular basally; anthers erect or ascending. Ovary spherical or shortly oblong, 3 -celled, with numerous ovules in each cell; style filiform, short or exceeding the stamens, the tips of style branches acting as receptive stigmatic surfaces; ovary similar in colour to foliage. Capsules dark brown or black, sometimes with purplish tinge, \pm globose, 4-7 $\mathrm{mm}$ long; fruiting pedicel spreading or ascending. Seeds globose to obconic, lacking obvious depression, 0.5-1.2 mm long, rugulose.

Flowering period: March - July; fruiting period: June - August.

Specimens examined: Turkey: A8 Artvin, Hopa, Kemalpaşa, damp roadside, grassland, $20 \mathrm{~m}$, 8 June $2013,41^{\circ} 30^{\prime} 30^{\prime \prime} \mathrm{N}, 41^{\circ} 32^{\prime} 16^{\prime \prime} \mathrm{E}$, Ö. Emin. 15855 (ARTH 5248); Artvin, Hopa, Hopa to Borçka roadside, gravelly soil, $270 \mathrm{~m}, 21$ June 2013, 41 ${ }^{\circ} 23^{\prime} 42^{\prime \prime} \mathrm{N}, 41^{\circ} 29^{\prime} 54^{\prime \prime} \mathrm{E}$, Ö. Emin. 16948 (ARTH 5249); Artvin, Hopa, Kemalpaşa, damp roadside, grassland, 3 m, 8 May 2014, $41^{\circ} 30^{\prime} 16^{\prime \prime} \mathrm{N}, 41^{\circ} 32^{\prime} 07^{\prime \prime} \mathrm{E}$, Ö. Emin. 19361 (ARTH 5266).

Distribution: Austria, Brazil, Canada, Colombia, Czechoslovakia, Germany, Great Britain, Mexico, United States, Russia and Georgia. New to Turkey.

Ecology: Sisyrinchium angustifolium grows on damp, humid and gravelly soil including roadsides and forest sides at 20-300 m with Plantago major L., Polygonum aviculare L, Oxalis corniculata L., Equisetum fluviatile L., and Juncus effusus L. 
Conservation status: Sisyrinchium angustifolium is only known from two localities in Artvin district. The natural habitat of the species is under threat due to animal grazing and road construction. In this state, according to the IUCN (2013), the species is considered to be vulnerable (VU B2b(ii) - the estimated area of occupancy is less than $2.000 \mathrm{~km}^{2}$, and the field observations indicate a continuing decline of habitat quality). Therefore, S. angustifolium should be included in the List of Threatened Species of Turkey's Flora.
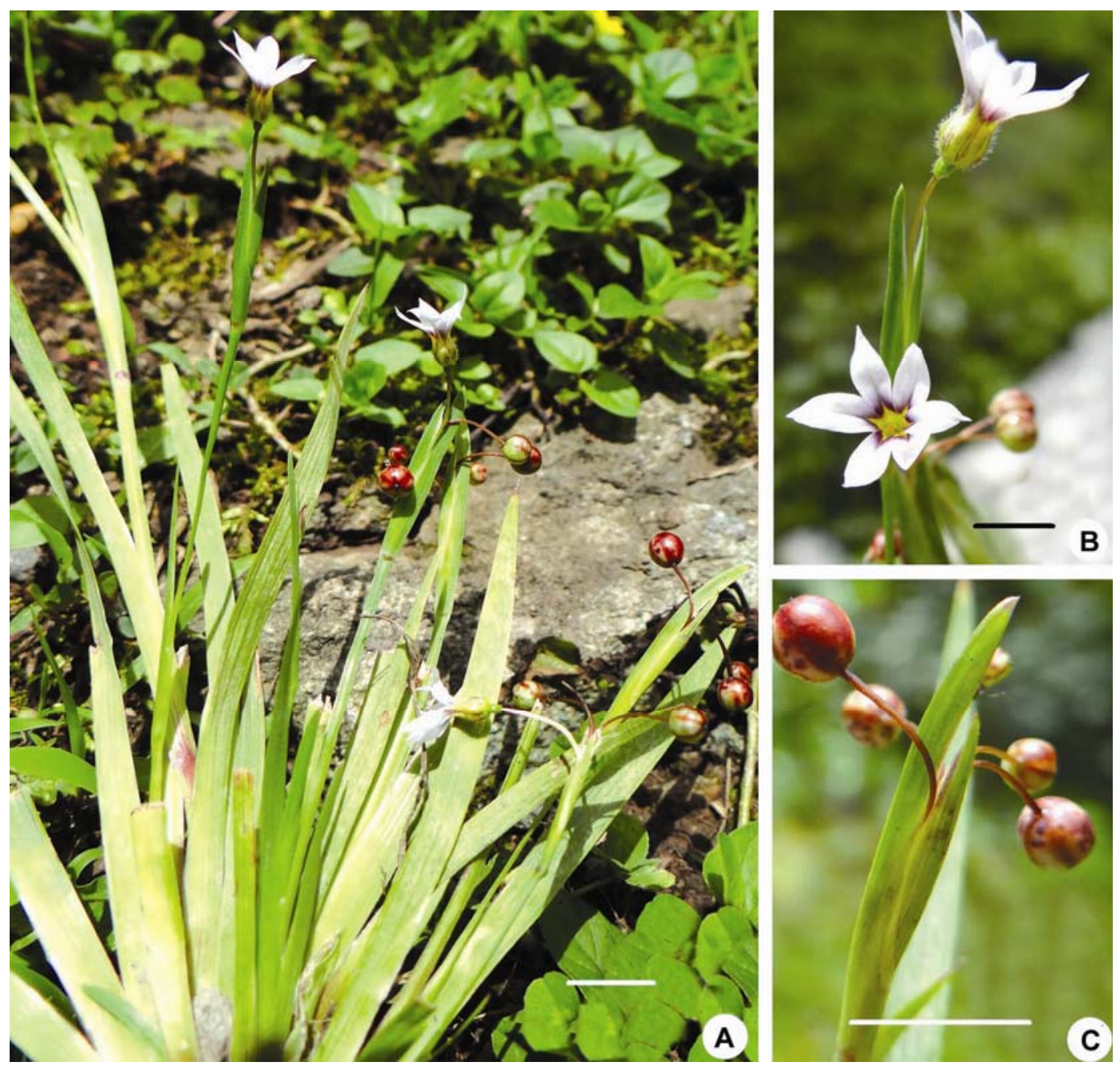

Fig. 1. Sisyrinchium angustifolium; A. Habitat; B. Front and lateral view of the flowers; C. Capsules. Scale bars: $\mathrm{A}, \mathrm{B}=1 \mathrm{~cm} ; \mathrm{C}=0.5 \mathrm{~cm}$

Anatomical characteristics:

Anatomical studies reveal that stem is ancipital in two directions. The epidermis contains a single layer of cells. Cuticle is very thick and cell walls of the epidermis are prominently thickened. There is no papilla above the epidermis. Several sunken stomata are observed in this 
layer. Mechanical tissue does not develop. Collateral vascular bundles in two circles and surrounded by sclerenchymatic ring. The larger bundles are present near to the centre (Fig. 2).

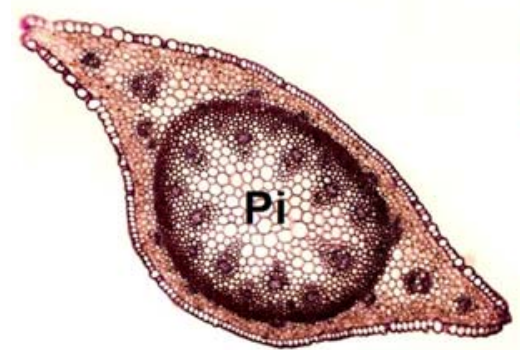

A

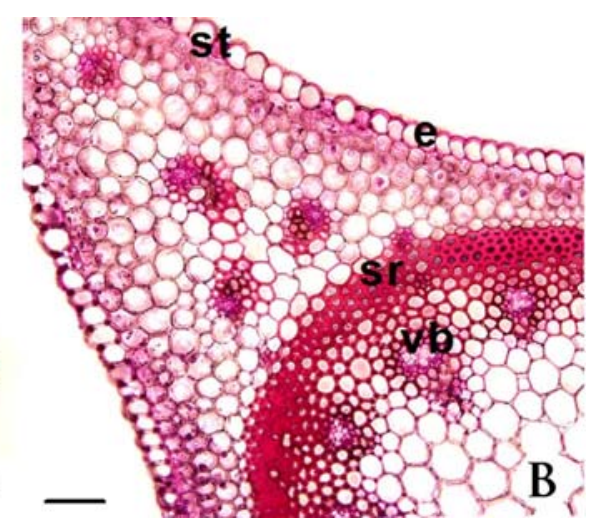

Fig. 2. Stem anatomy of Sisyrinchium angustifolium; A. Cross section of stem; B. Vascular bundles in stem. e: epidermis, pi: pith, sr: sclerenchymatic ring, st: stomata, vb: vascular bundle. Scale bars: A $=200 \mu \mathrm{m}$; $\mathrm{B}=50 \mu \mathrm{m}$.
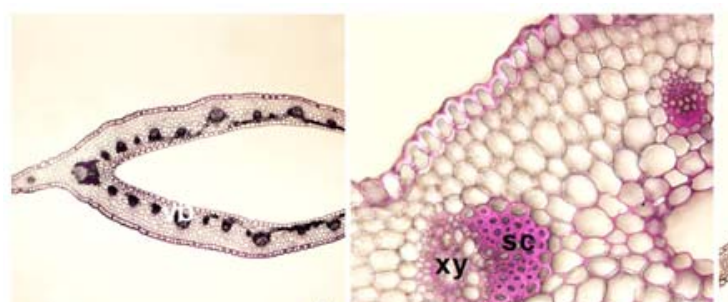

A

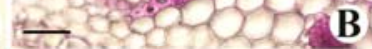

B -

C

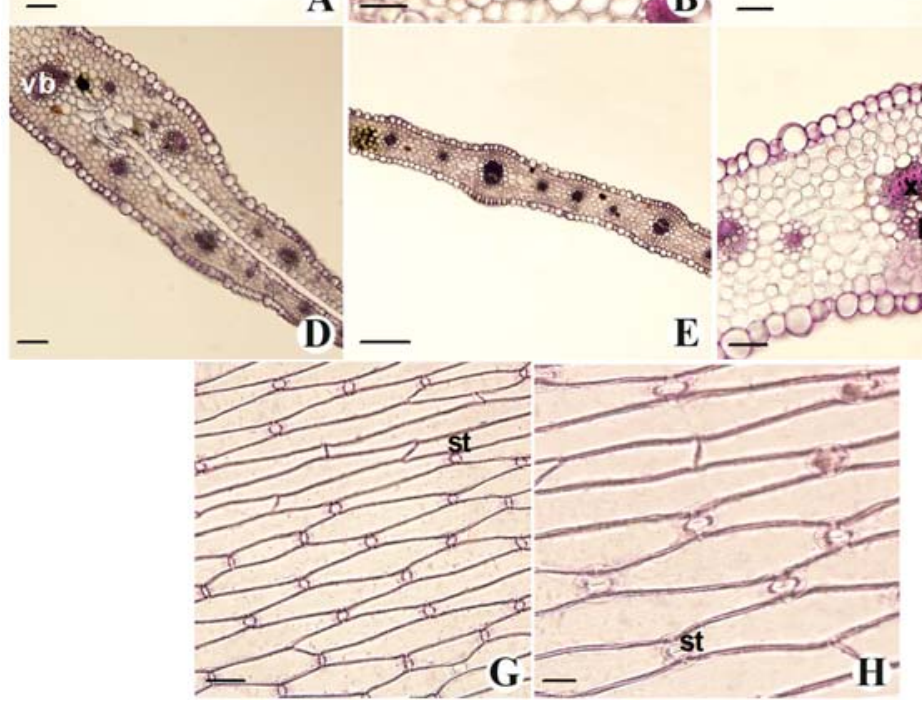

Fig. 3. Leaf anatomy of Sisyrinchium angustifolium. A-F. Cross section of leaf; G,H. Peripheral section. ph: phloem, sc: sclerenchymatic cap, st: stomata, xy: xylem, Scale bars: A,C,E $=200 \mu \mathrm{m} ; \mathrm{D}=100 \mu \mathrm{m}$; $\mathrm{B}, \mathrm{F}, \mathrm{G}=50 \mu \mathrm{m} ; \mathrm{H}=20 \mu \mathrm{m}$. 
The innermost part of the cylinder is occupied by a pith with thick-walled parenchyma. In some cases, hollow areas were observed instead of these cells in the center. The sheathing base is unifacial with both abaxial and adaxial epidermis, and leaf blade is unifacial, with an abaxial epidermis only. Surfaces do not contain any trichomes. The cuticle is smooth, epidermal cells of both surfaces are arranged in a single layer. Adaxial epidermal cells are thin-walled and stomata are absent in this surface, whereas abaxial epidermal cells are thick-walled, longer and narrower over veins than in intercostals areas (Fig. 3A-F). In the leaf blade, mesophyll is almost entirely chlorenchymatic. Vascular bundles with different sizes are collateral and surrounded by parenchymatous sheath cells, and they are arranged in a single row. Sclerenchymatic caps are observed in xylem pole. In peripheral sections, cells next to the stomata sometimes with slightly protruding over guard cells. Stomata are anomocytic in abaxial parts and sunken (Fig. 3G, H).

Mechanical tissue does not exist in the stems of examined samples. This feature has been previously reported in Sisyrinchium by Holm (1908). Leaf blade are longitudinally furrowed and vascular bundles with sclerenchymatic cap at the xylem poles. The study also reveals that sunken stomata are only found in abaxial surface. Rudall et al. (1986) investigated anatomical and chromosomal characteristics of 11 taxa and reported in these characteristics in the section of Bermudiana in Sisyrichium which is supported by the present study.

\section{Cytological investigation:}

In the present study the somatic chromosome number in Sisyrinchium angustifolium has been determined as $2 n=4 x=32$ (Fig. 4 ).

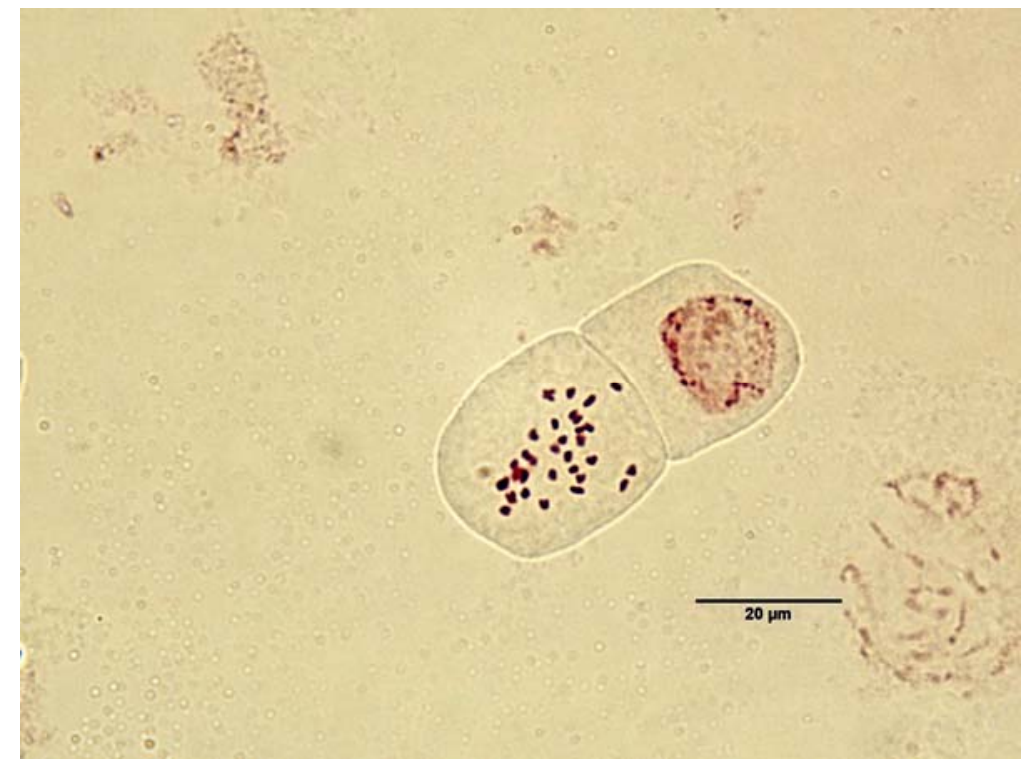

Fig. 4. Somatic metaphase of Sisyrinchium angustifolium. $2 n=32$

Basic chromosome number of the genus Sisyrinchium has been reported by Oliver and Lewis (1962) as $x=8,9$ and 17. In addition, Rudal et al. (1986) reported that basic chromosome number of the section of Bermudiana as $\mathrm{x}=8$ in the genus. This species belongs to the section Bermudiana. Our chromosome count from Eastern Anatolia is the first tetraploid level in $S$. 
angustifolium. Till now, only one previous record in a dodecaploid level $(2 n=12 x=96)$ for this species has been reported by Murin and Majovsky (1976).

\section{Acknowledgements}

The authors are thankful to the Ziraat Bank in Turkey and the Research Fund of Artvin Coruh University (project number: 2012.F15.02.21) for their financial supports.

\section{References}

Algan, G. 1981. Bitkisel Dokular İçin Mikroteknik, İstanbul. Fırat University Science Faculty Press (in Turkish).

Bicknell, E.P. 1899. Studies in Sisyrinchium IV: S. angustifolium and related species of the West and Northwest. Bull. Torrey Bot. Club 26: 445-457.

Davis, P.H. (Ed.) 1984. Flora of Turkey and the East Aegean Islands. Vol. 8. Edinburgh University Press, Edinburgh, $632 \mathrm{pp}$.

Davis, P.H. (Ed.) 1988. Flora of Turkey and the East Aegean Islands.Vol. 10. Edinburgh University Press, Edinburgh, $590 \mathrm{pp}$.

Eminağaoğlu, Ö. and Özcan, M. 2013. Euonymus leiophloeus (Celastraceae) - A new record for the flora of Turkey. Bangladesh J. Plant Taxon. 20(2): 263-266.

Eminağaoğlu, Ö., Özcan, M. and Kültür, Ş. 2012. Contributions to the leaf and stem anatomy of Tradescantia fluminensis: an alien species new to the flora of Turkey. ACU J. For. Fac. 13(2): 270-277.

Fedchenko, B.A. 1968. Sisyrinchium angustifolium Mill. In: Komarov, V.L. (Ed.), Flora of the U.S.S.R. Vol.4, Jerusalem: Israel Program for Scientific Translation, pp. 577-578.

Güner, A., Özhatay, N., Ekim, T. and Başer, K.H.C. (Eds). 2000. Flora of Turkey and the East Aegean Islands. Vol. 11. Edinburgh University Press, Edinburgh, 680 pp.

Holm, T. 1908. Sisyrinchium: Anatomical studies of North American species. Bot. Gaz. 46(3): 179-192.

IUCN 2013. The IUCN red list of threatened species, version 2013.1. IUCN Red List Unit, Cambridge, U.K. http://www.iucnredlist.org [accessed on 31 October 2013].

Murin, A. and Majovsky, J. 1976. In IOPB chromosome number reports LIII. Taxon 25: 483-500.

Oliver, R.L. and Lewis, W.H. 1962. Chromosome numbers of Sisyrinchium (Iridaceae) is Eastern North America. Sida 1: 43-48.

Ozcan, M., Hayırlığlu-Ayaz, S. and Inceer, H. 2008. Chromosome counts of some Cirsium (Asteraceae, Cardueae) taxa from Turkey. Caryologia 61(4): 375-382.

Özhatay, F.N., Kültür, Ş. and Gürdal, M.B. 2011. Checklist of additional taxa to the supplement Flora of Turkey V. Turk. J. Bot. 35: 589-624.

Rudall, P., Kenton, A.Y. and Lawrence, T.J. 1986. An anatomical and chromosomal investigation of Sisyrinchium and allied genera. Bot. Gaz. 147(4): 466-477.

Vardar, Y. 1987. Botanikte Preparasyon Teknigi. Izmir, Ege University Science Faculty Press (in Turkish).

(Manuscript received on 10 June 2014; revised on 29 November 2014) 